\title{
Standardization of a multiplex PCR for the identification of coagulase-positive Staphylococcus
}

\author{
Padronização de um multiplex PCR para identificação de estafilococos coagulase positiva
}

\section{Eliezer Avila GANDRA ${ }^{1 \star}$, Maria Aparecida FERNANDEZ², Jorge Adolfo SILVA³ ${ }^{3}$ Wladimir Padilha da SILVA ${ }^{3}$}

\begin{abstract}
The enterotoxigenic species Staphylococcus aureus, S. hyicus and S. intermedius show very similar characteristics, making their identification through conventional microbiological methods difficult. This study aimed at the development of a Multiplex PCR (mPCR) for the identification of $S$. aureus, $S$. intermedius and S. hyicus using the nuc gene as the target sequence. The results obtained suggest that the set of primers used was specific for the three species of Staphylococcus evaluate with a detection limit of $10^{2} \mathrm{CFU} \cdot \mathrm{mL}^{-1}$.
\end{abstract}

Keywords: S. aureus; S. hyicus; S. intermedius; PCR; nuc gene.

\section{Resumo}

As espécies enterotoxigenicas Staphylococcus aureus, S. hyicus e S. intermedius apresentam características muito similares, tornando difícil a sua identificação através dos métodos microbiológicos convencionais. Este trabalho visou o desenvolvimento de um PCR multiplex (mPCR) para a identificação $S$. aureus, S. intermedius and S. hyicus, utilizando, para isso, sequencias do gene nuc. Os resultados obtidos sugerem que os primers utilizados foram específicos para as três espécies de Staphylococcus avaliadas, com um limite de detecção de $10^{2} \mathrm{UFC} \mathrm{mL}^{-1}$.

Palavras-chave: S. aureus; S. hyicus; S. intermedius; PCR; gene nuc.

\section{Introduction}

The Staphylococcus genus is composed of 41 species and 24 sub-species, of which, only S. aureus, S. hyicus and S. intermedius (which belong to the coagulase positive staphylococcus (CPS) group) are associated with outbreaks of food intoxication (JAY, 2001). These three species show very similar morphologic characteristics when inoculated onto selective and differential media commonly used in laboratories (DOWNES; ITO, 2001). In addition, the coagulase and thermonuclease tests frequently used for the identification of staphylococcus species may not be enough to identify and differentiate the three species or to ascertain whether these microorganisms are present in foods (DOWNES; ITO, 2001).

Several authors have suggested the use of molecular methods, for example, amplification of specific sequences of the microbial genome by PCR, as a viable alternative to the traditionally used morphological and biochemical methods (SILVA et al., 2003; BARON et al., 2004; BECKER et al., 2005; CREMONESI et al., 2005; YANG et al., 2007).

One of the methodologies that has been widely used in the last few years for bacterial identification is Multiplex PCR (mPCR), in which more than one pair of primers are used in the same reaction allowing the simultaneous amplification of several DNA sequences (TAMARAPU et al., 2001 ). Therefore, it is possible to identify more than one bacterial species in the same PCR reaction affording a broader as well as faster analysis of the presence of pathogenic bacteria in foods (TAMARAPU et al., 2001).

In the search for quicker and more efficient methods for detection and identification of food pathogens, it was proposed the development and the evaluation of specificity and detection limits of a mPCR for the identification of the three CPS species, S. aureus, S. intermedius, and S. hyicus using primers specific for the nuc gene sequence, which codes for the production of a thermostable endonuclease enzyme (thermonuclease or TNase).

\section{Material and methods}

\subsection{Bacterial strains}

Two isolates, previously identified as S. hyicus and $S$. intermedius through biochemical and molecular tests by Silva et al. (2003) and standard strains of Staphylococcus aureus (ATCC 10832, ATCC 29213 and FRI-100), Staphylococcus epidermidis (ATCC 14990), Listeria monocytogenes (ATCC 764), and Escherichia coli (ATCC 11229) were used.

\subsection{DNA extraction}

Genomic DNA extraction was performed according to the protocol proposed by Matthews et al. (1997) from cultures

Received 19/3/2010

Accepted 4/9/2010 (004745)

${ }^{1}$ Centro de Ciências Químicas, Farmacêuticas e de Alimentos, Universidade Federal de Pelotas - UFPEL, Prédio 04, Campus do Capão do Leão, CP 354, CEP 96010-900,

Pelotas, RS, Brasil,e-mail: eliezer.gandra@ufpel.edu.br; gandraea@hotmail.com

2 Departamento de Biologia Celular e Genética, Universidade Estadual de Maringá - UEM, Maringá, PR, Brasil

${ }^{3}$ Departamento de Ciência e Tecnologia Agroindustrial, Faculdade de Agronomia "Eliseu Maciel", Universidade Federal de Pelotas - UFPEL, Pelotas, RS, Brasil

${ }^{*}$ Corresponding author 
isolated in Baird-Parker Agar (BPA, Merck ${ }^{\circledR}$ ) medium for CPS and in Tripticase Soy Agar (TSA, Merck ${ }^{\circ}$ ) for the other species. For the detection limit of mPCR analysis, the cultures were grown in Brain Heart Infusion (BHI, Oxoid ${ }^{\circledR}$ ). In this last case, DNA was extracted from five serial concentrations $\left(5 \times 10^{1}, 10^{2}, 10^{3}, 10^{4}\right.$, and $\left.10^{5} \mathrm{CFU} \cdot \mathrm{mL}^{-1}\right)$ and quantified by colony counting after spreading onto BPA $\left(\mathrm{Merck}^{\star}\right)$. For the quantification of DNA, optical density $(\mathrm{OD})$ readings were taken by absorbance at two wavelengths, 260 and $280 \mathrm{~nm}$. When the relationship between the two readings was equal to or greater than 1.8 and less than or equal to 2.0, the concentration of DNA was determined using the relation: $\mathrm{DO} 260=1.0$ corresponds to $50 \mathrm{~g}$ of DNA. The concentrations (bacterial in CFU.mL ${ }^{-1}$ or DNA in $\mu \mathrm{g} \cdot \mathrm{mL}^{-1}$ ) of microorganisms used as negative controls (S. epidermidis, L. monocytogenes, and E. coli) were the same as those used for the CPS species.

\subsection{Primer design}

The choice of the $n u c$ gene was based on the fact that the three species under study were able to produce the thermonuclease enzyme and, therefore, carry the nuc gene, and on the high correlation between this gene and the production of enterotoxins (CREMONESI et al., 2005). The oligonucleotides (primers) were synthetized by Invitrogen. The sequence, as well as the molecular size of the amplification product and the target species for each pair of primers, is presented in Table 1.

The primers were based on complete sequences of the nuc gene specific for each of the three species of CPS and obtained from GenBank/NCBI (access number NC_002745 for S. aureus, L23973 for S. hyicus and X67678 for S. intermedius). The selected sequences were aligned among themselves as well as with other bacterial species using the software Blast/GenBank/ NCBI (ALTSCHUL et al., 1997) to verify the existence of homologous regions among the nuc genes in the three species. It was taken into consideration that the primers had to anneal in the non-homologous regions in order to allow species-specific amplifications.

\subsection{Multiplex PCR}

For the detection limit study, the reactions contained $20 \mathrm{ng}$ of DNA for specificity evaluation or $1 \mu \mathrm{L}$ of DNA solution (with concentration varying from 0.83 up to $46.10 \mu \mathrm{g} \cdot \mathrm{mL}^{-1}$ ) extracted from BHI. To these reactions, were added: $1 \mu \mathrm{M}$ of each primer, $200 \mu \mathrm{M}$ of each triphosphate desoxinucleotide (dNTP,

Table 1. Oligonucleotides used for the identification of S. aureus, S. intermedius, and S. hyicus, products of $\mathrm{MPCR}$, and target species.

\begin{tabular}{lccc}
\hline Primer & Sequence 5'-3' & $\begin{array}{c}\text { Amplification } \\
\text { product (bp) }\end{array}$ & Species \\
\hline NUC1 & ATGAAGTCAAATAAATCGCT & 458 & S. aureus \\
NUC2 & TTTGGTGAAAAATACTTCTC & & \\
NUC3 & AAAAATAACAACAGGATTGA & 270 & S. hyicus \\
NUC4 & GTAAAGTCTGAAGCTTCTTT & & \\
NUC5 & GAAAAAAATTACAACAGGCG & \multirow{2}{*}{106} & S. intermedius \\
NUC6 & CACATCCGTTGAAGACTTTT & & \\
\hline
\end{tabular}

Invitrogen), $1 \mathrm{U}$ of Taq DNA Polymerase (Invitrogen, $5 \mathrm{U} \cdot \mu \mathrm{L}^{-1}$ ), $2 \mathrm{mM}$ of $\mathrm{MgCl}_{2}$ (Invitrogen), and $4 \mu \mathrm{L}$ of $10 \mathrm{X}$ buffer (Invitrogen) reaching the final volume of $40 \mu \mathrm{L}$. The amplification program consisted of 2 minutes at $94^{\circ} \mathrm{C}, 2$ minutes at $55^{\circ} \mathrm{C}$, and 3 minutes at $72^{\circ} \mathrm{C}$, for 40 cycles. The amplification products were analyzed in $1 \%$ agarose gel $(\mathrm{w} / \mathrm{v})$ and stained with $0.5 \mu \mathrm{g} \cdot \mathrm{mL}^{-1}$ of ethidium bromide. All the strains were submitted to three processes of amplification with DNA extracted in different days.

\section{Results and discussion}

\subsection{DNA extraction}

The concentrations of the samples of DNA used in the evaluation of the specificity of the method used were corrected for $20 \mathrm{ng}$ before use in mPCR. Nevertheless, the samples used in the study for the detection limit did not have a modified concentration and were quantified. The averages are shown in Table 2.

\subsection{Specificity}

The primer pairs NUC1 and 2, NUC3 and 4, and NUC5 and 6 were individually tested for all species evaluated in this study. There was no amplification when DNA from microorganisms that did not harbor the corresponding genes was used as a template source. The mPCR products obtained from each of the species evaluated by DNA amplification are shown in Figure 1.

NUC1 and NUC2 primers demonstrated specificity for $S$. aureus because only in the reactions in which DNA from this species was present the estimated $458 \mathrm{pb}$ fragment was amplified (Figure 1, column 2). This result is in accordance with those previously reported by Kim et al. (2001) and Tamarapu et al. (2001), who developed an mPCR for the detection of the nuc gene sequence of $S$. aureus and also verified a sequence of this gene specifically for the identification of this bacterium.

NUC3 and NUC4 primers were specific for S. hyicus with amplification of a fragment of the expected size only when the S. hyicus DNA was used (Figure 1, column 3). It is known that the sequence of amino acids that originated from the nuc gene of $S$. hyicus is highly homologous to the TNAse produced by $S$. aureus and by $S$. intermedius. However, the differences in the nucleotide sequence among the $n u c$ genes in the three species allow their use as a species-specific maker, as reported by Silva et al. (2003), who used sequences of this gene as a molecular

Table 2. Average of the DNA extracted concentrations from the serial concentrations of S. aureus, S. intermedius, and S. hyicus.

\begin{tabular}{cccc}
\hline $\begin{array}{c}\text { Microorganisms } \\
\text { concentrations } \\
(\text { CFU.mL }\end{array}$ & \multicolumn{3}{c}{$\begin{array}{c}\text { Average of DNA } \\
\text { concentrations }\left(\mu \mathrm{g} . \mathrm{mL}^{-1}\right)\end{array}$} \\
\cline { 2 - 4 } & S. aureus & S. hyicus & S. intermedius \\
\hline $5 \times 10^{1}$ & 0.83 & 1.43 & 1.53 \\
$10^{2}$ & 6.30 & 5.93 & 6.87 \\
$10^{3}$ & 14.10 & 13.40 & 15.23 \\
$10^{4}$ & 31.80 & 28.73 & 36.00 \\
$10^{5}$ & 40.77 & 43.73 & 46.10 \\
\hline
\end{tabular}


marker specific for S. hyicus and, as done in the present study, to differentiate this microorganism from $S$. aureus and from S. intermedius NUC5 and NUC6 primers initially produced a large number of fragments when S. intermedius DNA was submitted to amplification (data not shown). However, the estimated fragment (106 pb) was always obtained. A similar result was reported by Silva et al. (2003), who also verified nonspecific bands when nuc gene sequences were used to identify $S$. intermedius. The high percentage of adenine and thymine, together with the low annealing temperature used, favored the appearance of these fragments. The increase in the annealing temperature increased the stringency of the reaction. Among

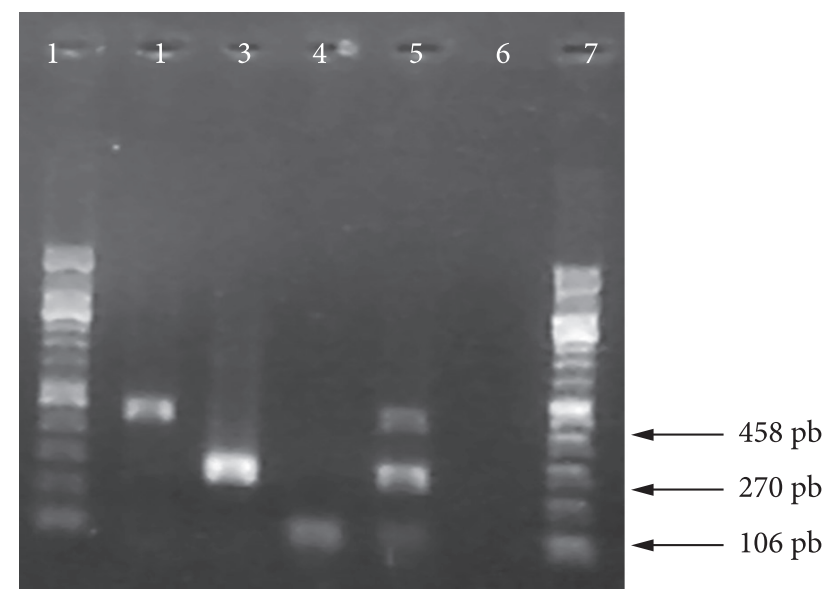

Figure 1. mPCR products obtained with NUC1-NUC2, NUC3-NUC4 and NUC5-NUC6 primers, analyzed under UV light, in 1\% agarose gel (w/v), stained with $0.5 \mu \mathrm{g} \cdot \mathrm{mL}^{-1}$ of ethidium bromide. 1) $100 \mathrm{bp}$ standard molecular weight Marker (100 bp DNA Ladder, England Biolabs ${ }^{\circledast}$ ); 2) S. aureus ATCC 29213,3$)$ S. hyicus isolate, 4) S. intermedius isolate, 5) mix S. aureus ATCC 29213, S. hyicus and S. intermedius isolates, 6) negative control 1 (S. epidermidis ATCC 14990), and 7) standard molecular weight Marker (100 bp DNA Ladder, England Biolabs). the tested temperatures, $55^{\circ} \mathrm{C}$ presented the best performance in terms of the estimated fragment size. This temperature was also used by Baron et al. (2004), who used species-specific sequences of nuc gene and obtained a discrimination level of 100\% among 44 strains of $S$. aureus and 57 strains of $S$. intermedius isolated from different sources. Other authors, such as Sánchez et al., (2003), also had to optimize annealing temperatures during the calibration of an MPCR and reported that low temperatures can drive reactions with low specificity and detection limits due to the competition between non-specific products over the components of the reaction.

\subsection{Detection limit}

It was possible to amplify DNA to up to $10^{2} \mathrm{CFU} \cdot \mathrm{mL}^{-1}$ for the species of S. aureus, S. hyicus, and S. intermedius (Figures 2,3). For the latter, DNA amplification was also obtained from $5 \times 10^{1}$ CFU. $\mathrm{mL}^{-1}$. However, this result was not reproducible (Figure 3). Therefore, the minimum detection limit for all species was shown to be $10^{2} \mathrm{CFU} \cdot \mathrm{mL}^{-1}$.

Other authors have also studied the detection limits of mPCR for Staphylococcus identification in isolated cultures as well as in food. Tamarapu et al. (2001) used sequences of $n u c$ and $e n t C$ genes for the identification of standard strains of S. aureus in artificially contaminated milk and dairy product. They also verified a detection limit around $10^{2}$ CFU. $\mathrm{mL}^{-1}$. Other authors have also reported lower detection limits. For example, Sánchez et al. (2003) detected enterotoxigenic strains of Staphylococcus aureus in culture medium up to the limit of $10^{1} \mathrm{CFU}$ and Yang et al. (2007) used sequences of $n u c$ genes for the identification of $S$. aureus in milk and dairy products. These authors verified a detection limit around $10 \mathrm{CFU} \cdot \mathrm{mL}^{-1}$.

The difference in detection limits between this study and the results previously reported by other authors may be associated with the reaction itself because, as suggested by Chamberlain and Chamberlain (1994), the competition among the primer
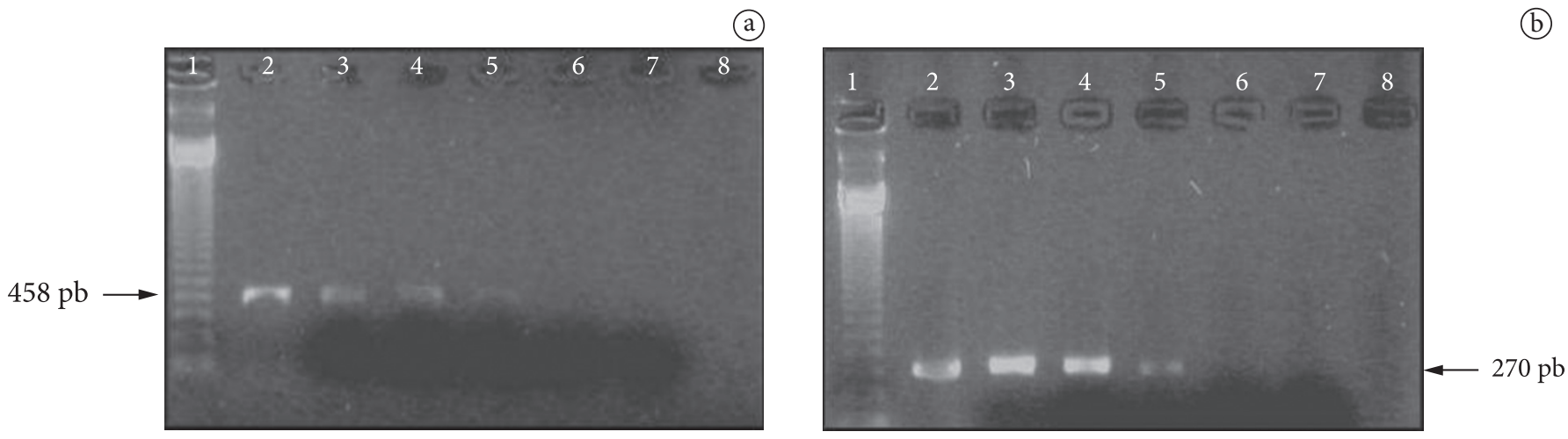

Figure 2. a) mPCR products with DNA extracted from serial concentrations of S. aureus ATCC 29213, analyzed under UV light, in 1\% agarose gel (w/v), stained with $0.5 \mu \mathrm{g} \cdot \mathrm{mL}^{-1}$ of ethidium bromide. 1) $123 \mathrm{bp}$ standard molecular weight Marker (2log DNA Ladder, England Biolabs ${ }^{\circledR}$ ); 2) $10^{5} \mathrm{UFC} . \mathrm{mL}^{-1}$; 3) $10^{4} \mathrm{UFC} . \mathrm{mL}^{-1}$; 4) $10^{3} \mathrm{UFC} . \mathrm{mL}^{-1}$; 5) $10^{2} \mathrm{UFC} . \mathrm{mL}^{-1}$; 6) $5 \times 10^{1} \mathrm{UFC} . \mathrm{mL}^{-1}$; 7) negative control 1 (E. coli ATCC 11229), 8) negative control 2 (Listeria monocytogenes ATCC 764). b) mPCR products with DNA extracted from serial concentrations of $S$. hiycus isolate, analyzed under UV light, in $1 \%$ agarose gel (w/v), stained with $0.5 \mu \mathrm{g} \cdot \mathrm{mL}^{-1}$ of ethidium bromide. 1) Marker (2log DNA Ladder, England Biolabs ${ }^{\oplus}$ ); 2) $10^{5}$ UFC.mL ${ }^{-1}$; 3) $10^{4}$ UFC.mL ${ }^{-1}$; 4) $10^{3}$ UFC.mL ${ }^{-1}$; 5) $10^{2}$ UFC.mL ${ }^{-1}$; 6) $5 \times 10^{-1} \mathrm{UFC}_{\mathrm{mL}} \mathrm{U}^{1}$, 7) negative control 1 (E. coli ATCC 11229), and 8) negative control 2 (Listeria monocytogenes ATCC 764). 


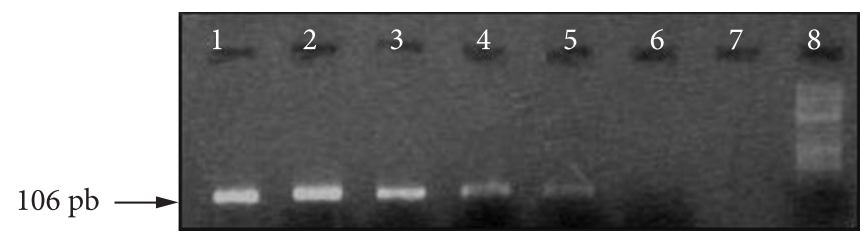

Figure 3. mPCR products with DNA extracted from serial concentrations of $S$. intermedius isolate, analyzed under UV light, in $1 \%$ agarose gel $(\mathrm{w} / \mathrm{v})$, stained with $0.5 \mu \mathrm{g} \cdot \mathrm{mL}^{-1}$ of ethidium bromide. 1) $10^{5} \mathrm{UFC} . \mathrm{mL}^{-1}$; 2) $10^{4} \mathrm{UFC} . \mathrm{mL}^{-1}$; 3) $10^{3} \mathrm{UFC} . \mathrm{mL}^{-1}$; 4) $10^{2} \mathrm{UFC} . \mathrm{mL}^{-1}$; 5) $\left.5 \times 10^{1} \mathrm{UFC} . \mathrm{mL}^{-1}, 6\right)$ negative control 1 (E. coli ATCC 11229), 7) negative control 2 (Listeria monocytogenes ATCC 764), and 8) $100 \mathrm{bp}$ standard molecular weight Marker (100 bp DNA Ladder, England Biolabs ${ }^{\circledast}$.

pairs in mPCR can effectively contribute to a decrease in detection limits. Additionally, as reported by Tamarapu et al. (2001), differences in detection limits found in studies with mPCR can be associated with the presence of contaminants in DNA preparations.

It is important to emphasize that even though this study was carried out with isolated strains the detection limit $\left(10^{2}\right.$ CFU.mL $\left.{ }^{-1}\right)$ was acceptable for a CPS identification method, considering that, in foods in which these pathogens represent microbiological hazards, several legislations establish $10^{3}$ CFU.mL ${ }^{-} 1$.as the maximum allowed limit. In addition to this legal definition of contamination levels, the production of enterotoxins in CPS occurs only when these microorganisms reach more than $10^{5}$ CFU.g ${ }^{-1}$ of food (JAY, 2001).

The usual method for S. aureus, S. hyicus, and S. intermedius identification, involving inoculation in a selective-differential medium followed by confirmation with a coagulase test (DOWNES; ITO, 2001), is not sufficiently discriminatory for these three CPS species. However, considering that these microorganisms can cause food intoxication, this differentiation of the three CPS species is particularly important in an epidemiological investigation.

The time required for the analysis is made shorter by the method based on MPCR when compared to the usual and traditional biochemical methods. With the molecular approach used in this study, the results can be obtained in 24 hours. The biochemical methods traditionally used to identify CPS demand a longer time for analysis ( 48 to 72 hours) because it is necessary to perform several tests for identification at the species level. It is also necessary to take into consideration that, in the majority of biochemical tests, variability of the results can occur with the occurrence of false-negative results, a result of the action of environmental factors on gene expression (DOWNES; ITO, 2001). Considering the speed, specificity, and detection limit established, it can be inferred that the MPCR proposed in this study can be used as a first step in studies of detection of microorganisms in food.

\section{Conclusions}

The mPCR proposed in this study, due to the specificity and detection limit presented, as well as the fact that it is based on genetic characteristics and is therefore stable, has potential to be used in the rapid and accurate identification of the three species of CPS capable of causing staphylococcal intoxication.

\section{References}

ALTSCHUL, S. F. et al. Gapped BLAST and PSI-BLAST: a new generation of protein database search programs. Nucleic Acids Research, v. 25, n. 17, p. 3389-3402, 1997. PMid:9254694. PMCid:146917. http://dx.doi.org/10.1093/nar/25.17.3389

BARON, F. et al. Development of a PCR test to differentiate between Staphylococcus aureus and Staphylococcus intermedius. Journal of Food Protection, v. 67, n. 10, p. 2302-2305, 2004.

BECKER, K. et al. Thermonuclease gene as a target for specific identification of Staphylococcus intermedius isolates: Use of a PCR-DNA enzyme immunoassay. Diagnostic Microbiology and Infectious Disease, v. 51, n. 4, p. 237-244, 2005. PMid:15808314. http://dx.doi.org/10.1016/j.diagmicrobio.2004.11.010

CHAMBERLAIN, J. S.; CHAMBERLAIN, J. R. Optimization of multiplex PCRs. In: MULLIS; K. B.; FERRÉ, F.; GIBBS, R. A. The Polymerase Chain Reaction. Boston: Cambridge Birkhäuser, 1994. p. 38-45.

CREMONESI, P. et al. Development of a multiplex PCR assay for the identification of Staphylococcus aureus enterotoxigenic strains isolated from milk and dairy products. Molecular and Cellular Probes, v. 19, n. 5, p. 299-305, 2005. PMid:16006095. http://dx.doi. org/10.1016/j.mcp.2005.03.002

DOWNES, F. P.; ITO, H. Compendium of methods for the microbiological examination of foods. 4. ed. Washington: American Public Health Association - APHA, 2001. 676 p.

JAY, J. M. Gastroenterites estafilocócica. In: JAY, J. M. Microbiologia moderna de los alimentos. 4 ed. Zaragosa: Editorial Acribia S. A, 2001. p. 537-563.

KIM, C. H. et al. Optimization of the PCR for detection of Staphylococcus aureus nuc gene in bovine milk. Journal Dairy Science, v. 84, n.1, p. 74-83, 2001. http://dx.doi.org/10.3168/jds. S0022-0302(01)74454-2

MATTHEWS, K. R. et al. Identification and differentiation of coagulase-negative Staphylococcus aureus by polymerase chain reaction. Journal of Food Protection, v. 60, n. 6, p. 686-688, 1997.

SÁNCHEZ, G. N. et al. Development of Two Multiplex Polymerase Chain Reactions for the Detection of Enterotoxigenic Strains of Staphylococcus aureus Isolated from Foods. Journal of Food Protection, v. 66, n. 6, p. 1055-1062, 2003.

SILVA, W. P. et al. Identification of Staphylococcus aureus, S. intermedius, and S. hyicus by PCR amplification of $c o a$ and $n u c$ genes. Brazilian Journal of Microbiology, v. 34, n. 1, p. 125-127, 2003. http://dx.doi. org/10.1590/S1517-83822003000500043

TAMARAPU, S.; MCKILLIP, J. L.; DRAKE, M. Development of a multiplex polymerase chain reaction assay for detection and differentiation of Staphylococcus aureus in dairy products. Journal of Food Protection, v. 64, n. 5, p. 664-668, 2001.

YANG, Y.; SU, X.; YUAN, Y.; KANG, C.; LI, Y.; ZHANG, W.; ZHONG, X. Detection of Staphylococcus aureus in Dairy Products by Polymerase Chain Reaction Assay. Agricultural Sciences in China, v. 6, n. 7, p. 857-862, 2007. http://dx.doi.org/10.1016/S1671-2927(07)60122-9 